\title{
Relación de la Lactancia Materna y Hábitos de Succión no Nutritiva con Maloclusión Dental
}

\author{
ALFREDO MENDOZA ${ }^{1}$, PAOLA ASBÚN ${ }^{2}$, ANDREA CRESPO A. ${ }^{2}$, \\ SUSANA GONZALES ${ }^{2}$, ROSA PATIÑO ${ }^{2}$ \\ 1. Pediatra- Inmunoalérgologo. Jefe de la Unidad de Emergencias. Hospital del Niño "Dr. Ovidio Aliaga". La Paz-Bolivia. \\ 2. Odontopediatra, Universidad Nuestra Señora de La Paz. La Paz-Bolivia.
}

\begin{abstract}
Relation between maternal breast feeding and habits of non nutritive suction with dental altered occlusion

Objectives: To analyze the effects of the maternal breast feeding over the development of the different structures that compose the estomatognatico apparatus, its preventive effects. Design: Case control cohort retrospective longitudinal. Place: Hospital del Niño Dr. Ovidio Aliaga Uria, in the city of La Paz. Participants: 500 children between three ands seven years old that come to the outpatient clinic and emergency ward. Material and Methods: The information was obtained with previous consent from the parents, questionnaire given to the mothers, that included: general information, time of breastfeeding, type of feeding, non nutritive suction habits: also we examined the children in the study and take their records in a history chart including: sex, age, postlacteum plane, occlusion classifi cation, presence of habits, presence of anomalies and we studied the possible associations between them. Results: Of the 500 children studied, 250 cases and 250 controls; $47 \%$ ( $=$ $235)$ male and $53 \%(n=265)$ female. The exclusive maternal breastfeeding during the fi rst six months of life represents a preventive factor for the development of altered occlusion, OR of 0.09 with (IC 95\% 3.46-5.28). On the other hand feeding bottle feeding has a probability of altered occlusion OR of 18.2 (IC 95\% 4.23-4.79). We found a statistically signifi cant association between the habits of non nutritive suction and altered occlusion OR 24.57 (IC 95\% 2.55-3.01) between the fi rst three years of life. Depending of the type of feeding we observed that in those children who had feeding through bottle $64 \%$ had habits of non nutritive suction. The most frequent non nutritive suction habit is the digital suction with $53 \%$, representing less percentages the bottle feeding with $28 \%$ and other habits like the lip interposition and tongue with $19 \%$. Conclusions: The non nutritive suction habits and the bottle feeding in the fi rst months of life are the primary risk factor for the development of altered occlusion like deep bite in deciduous dentition and Class II of Angle in mixed dentition. (Key words: Maternal breastfeeding, non nutritive suction, bottle feeding, altered occlusion).

Rev Soc Bol Ped 2008; 47 (1): 3-7
\end{abstract}




\section{RESUMEN}

Objetivo: Analizar los efectos de la lactancia materna sobre el desarrollo de las diferentes estructuras que conforman el aparato estomatognático, su efecto preventivo. Diseño: Estudio caso control de cohorte longitudinal retrospectivo. Lugar: Hospital de Niño "Dr. Ovidio Aliaga Uría" de la ciudad de La Paz. Participantes: 500 niños entre tres y siete años de edad que asisten a los Servicios de Consulta externa y Emergencias del hospital. Material y Métodos: La información se obtuvo previa autorización de los padres, mediante un cuestionario aplicado a las madres, que incluía: datos generales, tiempo de lactancia, tipo de alimentación, hábitos de succión no nutritiva; además se examinaron a los niños objetos de estudio y se tomaron sus datos en una historia clínica que incluía; sexo, edad, plano postlácteo, clasificación de la oclusión, presencia de hábitos, presencia de anomalías y se estudiaron las posibles asociaciones entre ellas. Resultados: De los 500 niños estudiados, 250 fueron casos y 250 controles; $47 \%(n=235)$ varones y $53 \%(n=265)$ mujeres. La lactancia materna exclusiva durante los primeros seis meses de vida representa factor preventivo para el desarrollo de maloclusión, OR de 0,09 con (IC 95\% 3,46-5,28). Por el contrario la alimentación con biberón conlleva una probabilidad de maloclusión OR de18,2 (IC 95\% 4,23-4,79). Asimismo se encontró asociación estadísticamente significativa entre los hábitos de succión no nutritiva y la maloclusión OR 24,57 (IC 95\% 2,55-3,01) durante los tres primeros años de vida. Según el tipo de lactancia se observó que en aquellos niños que tuvieron alimentación con biberón el 64\% presentaron hábitos de succión no nutritiva. El hábito de succión no nutritiva más frecuente es la succión digital con un 53\%, representando menores porcentajes la succión de chupón con un $28 \%$ y otros hábitos como la interposición labial y lingual en un 19\%. Conclusiones: Los hábitos de succión no nutritiva y la alimentación con biberón en los primeros meses de vida son el principal factor de riesgo para el desarrollo de maloclusiones como mordida profunda en dentición decidua y Clase II de Angle en dentición mixta.

(Palabras clave: Lactancia materna, succión no nutritiva, biberones, maloclusión).

Rev Soc Bol Ped 2008; 47 (1): 3-7

\section{ESTE TRABAJO LO PUEDE ENCONTRAR EN EXTENSO EN WWW.SciELO.ORG}

